\title{
Effects of Brown Heroin and Tramadol Dependency on Reproductive Axis in Adult Male Albino Rats
}

\author{
Dalia I. A. Mesallam, Arwa A. El-Sheikh¹, Samaa Salah AbdEl-Fatah² and Noha M. Abedelsalam ${ }^{3}$ \\ ${ }^{1}$ Department of Forensic Medicine and Clinical Toxicology \\ 2 Department of Anatomy and Embryology \\ ${ }^{3}$ Department of Public Health and Preventive Medicine.
}

Faculty of Medicine, Zagazig University, Al-sharqia , Egypt.

\begin{abstract}
Objective: Drugs addiction is considered a general major problem all over the world causing massive detrimental effects for the addict, communities and governments. The study was designed to assess the dependency impact of concurrent brown heroin and Tramadol administration on reproduction in rats. Material and methods: Sixty adult male albino rats were divided into untreated control (I), vehicles groups citric acid (II), saline (III), brown heroin (IV), tramadol (V) and concurrent brown heroin and tramadol (VI) groups. The animals were treated daily for forty days by oral (saline and tramadol) and intra-peritoneal (citric acid and heroin) routes. The body weights, the reproductive hormonal assay (luteinizing hormone LH, follicle stimulating hormone FSH, free Testosterone, Estradiol E2 and prolactin PRL) and the hormones related gene expression (brain FSH-B gene, LH-B gene and testicular cytochrome 19 gene CYP-19) were evaluated. The histopathological changes of the brain and testis were demonstrated. Results: The brown heroin, tramadol and the concurrent brown heroin and tramadol administration reduced the rats' body weight, serum LH, FSH and Testosterone and increased the serum E2 and PRL levels. Moreover, both heroin and tramadol produced down regulation of brain LH-B and FSH-B with up regulation of testicular CYP-19 genes expression and induced histopathological alterations in both of the brain and testicular structures. Conclusion: The concurrent brown heroin and tramadol dependency affect the reproductive axis and impaired fertility in adult male albino rats via altering the circulating reproductive hormones and its related genes expression, moreover, affecting the histology of the brain and testis. Recommendation: Health education for the purpose of increasing public awareness regarding hazards of tramadol and heroin addiction, periodic urine screening for early detection and proper management which could be done for university students, employee in different community services....etc
\end{abstract}

\begin{tabular}{l|l} 
Keywords & Brown heroin, tramadol, reproductive hormones, gene expression, histopathology
\end{tabular}

\section{Introduction}

ddiction was and is still considered a major problem among communities and governments; it acts as a $\perp$ complex illness; characterized by repeated use and intense uncontrollable craving of a drug or multiple drugs in a way that is destroying both of self and community (Ghowsi and Yousofvand, 2015).

Illicit drug use is prevalent in our society and may adversely affect male fertility. Unfortunately, usage of these illicit substances often occurs during reproductive years or during critical periods of testicular development. Illicit drugs use as marijuana, opioid, narcotics, cocaine and methamphetamines, affects the hormonal axis and causes impairment in semen analysis and functional sperm parameters (Fronczak et al., 2012).

It is difficult to assess and control multiple illicit drug interactions because many illicit drug users are often taking more than one type of drug and also, interactions with other foods and drugs may affect the metabolism of an illicit drug (McCance et al., 1995). For example, heroin users are often mixing heroin with other addictive agents. Overdose risk and death may be substantially increased as drugs can interact by amplifying or masking the physiological effects on the body (Jones et al., 2012).

Heroin was and is still considered to be one of the most addictive agents. It is a crude preparation of diamorphine, a semisynthetic product obtained by acetylation of morphine, which is a natural product of opium, the dried latex of certain poppy species (e.g. Papaver somniferum L.) (King and McDermott, 2004).

Heroin may be smoked or dissolved in a weak acid and injected. After absorption, it is deacetylated into an inactive 3- monoacetylmorphine and the active 6monoacetylmorphine (6-MAM), and then to morphine, which bind to $\mu$-opioid receptors, resulting in the drug's euphoric, analgesic and anxiolytic effects. A quarter of heroin users become physically dependent. Other side effects can 
include abscesses, infected heart valves, blood borne infections, constipation, and pneumonia. After a history of long-term use, withdrawal symptoms can begin within hours of last use (Klous et al., 2005).

Tramadol that is used extensively now, has a centrally analgesic action. It possesses weak opioid action and is catecholamine and serotonin reuptake inhibitor. Tramadol is a synthetic opioid of the benzenoid class. In the body it is metabolized to O-desmethyltramadol, which is a more potent opioid (El-Ghawet, 2015).

Tramadol increases the serotonin levels, giving it the advantage over other addictive agents to use when their drugs of choice are not available to avoid withdrawal syndrome (Adams et al., 2006). The commonest reported side effects following repeated opioid and tramadol administration were hyperalgesia, tolerance and physical dependence (Akbari et al., 2013), and affection of steroidogenesis in adrenal and testicular tissues (Malik et al., 1992; Simin and Zahra, 2007 and Gholami et al., 2015).

Increasing infertility between street abusers, multiplicity of addicting agents and spreading of concurrent brown heroin and tramadol abuse as the commonest addicting agents in our country were the motivation factors for this work. Therefore, this study was designed to investigate the dependency impacts of brown heroin and tramadol together on reproduction hormones levels, expression of hormones related genes and to examine the pathological effects of both agents on brain and testis in adult male albino rats by using the usual methods of their administrations among addicts and to investigate the possible underlying molecular mechanisms.

\section{Material and methods}

\section{Animals}

Sixty adult male albino rats weighing 150-200 gm were obtained from the Animal House of the Faculty of Medicine, Zagazig University. They were housed in filter-top plastic cages (5 rats/cage) at a room temperature $\left(25 \pm 2{ }^{\circ} \mathrm{C}\right)$, humidity-controlled (55 $\left.\pm 5 \%\right)$, artificially illuminated room (12:12 h light/dark cycle) and allowed 1 week for acclimatization before the beginning of the experimental work. All animals were provided with standard rodent chow diet and allowed free access to drinking water. The experimental protocol was conducted in accordance with the guidelines of the Ethical Committee for Animal Handling, Faculty of Medicine, Zagazig University.

\section{Drugs}

Tramadol: Its chemical name is $(+)$ cis-2[(dimethylamino)methyl]-1-(3-m ethoxyph-enyl) cyclohexanol hydrochloride. 225mg tablets, was obtained from Mina- Pharm, Egypt. It was dissolved in normal saline solution $0.9 \%$ and was freshly prepared for each use.

Brown Heroin (Diamorphine or Diacetylmorphine) that which is used in Egypt, was provided by Drugs control administration within The Security Directorate in Zagazig, Al-Sharqia, Egypt. It was dissolved in citric acid and was diluted in normal saline solution $0.9 \%$.

Citric acid: whitish crystals, was obtained from El-Gomhoureya for Trading Drugs \& Medical Supplies, Zagazig, Al-Sharqia, Egypt.
Preparation of heroin according to the protocol of Othman (2013) where the brown heroin powder (250 mg) was mixed with citric acid (25 mg), then the mixture dissolved in $1 \mathrm{ml}$ normal saline solution $0.9 \%$ and mixed well and heated over flame until production of bubbles, the last obtained solution (after heating) was drawn by wide bore needle in $1 \mathrm{ml}$ syringe then diluted with normal saline solution $0.9 \%$ to 5 $\mathrm{mg} / \mathrm{ml}$.

\section{Experimental design}

The animals were weighed then divided into 6 groups as follows:

(I) Untreated control group (10 rats): The animals received only regular diet and tap water for 40 days to determine the basic values of performed tests.

Vehicles group subdivided into:

(II) Citric acid group (10 rats): this group was assigned for determining the effects of citric acid. The animals received intraperitoneal (i.p.) injection of citric acid (brown heroin solvent) and normal saline (diluent) twice daily for 2 days with the following manner ; in the $1^{\text {st }}$ day, they were injected by $0.5 \mathrm{ml}$ normal saline $+0.5 \mathrm{mg}$ citric acid $/ \mathrm{kg}$ b.w and $1 \mathrm{ml}$ normal saline $+1 \mathrm{mg}$ citric acid/kg bw in the $2^{\text {nd }}$ day. The last dose was then injected once a day for the rest of 40 days.

(III) Saline group (10 rats): the animals received normal saline (Tramadol solvent) (1ml once/day) by oral gavage.

(IV) Brown heroin group (10 rats): the animals received i.p. injection of brown heroin $(10 \mathrm{mg} / \mathrm{kg}$ b.w.) (Antonilli et al., 2003).

(V) Tramadol group (10 rats): the animals received oral tramadol (40mg/kg b.w.) (El-Ghawet, 2015), Once daily for 40 days where the LD50 of tramadol oral administration was around $300-350 \mathrm{mg} / \mathrm{kg}$ b.w (Matthiesen et al., 1998).

(VI) The concurrent brown heroin and tramadol group (10 rats): the animals received i.p. injection of brown heroin (10mg/kg b.w.)[14] Once daily for 20 days followed by oral tramadol (40mg/kg b.w.) (El-Ghawet, 2015), once daily for another 20 days to complete the study period of time 40 days. The doses for rats were calculated according to Paget and Barnes (1964).

Brown heroin and tramadol dependence was achieved by repeated graded dose regimen as described by Dambisya et al. (1991) by i.p. injection of $10 \mathrm{mg}$ of brown heroin and/or oral administration of $80 \mathrm{mg}$ of tramadol twice/ day in the first 2 days. The animals received brown heroin in the same dose and manner as pervious mentioned and the dose was justified according to the animal body weight.

At the end of the experiment, twenty-four hours after the final dosing day, the rats (had been fasted over-night) were weighed and venous blood samples were collected from retro-orbital plexus of each rat $(2 \mathrm{ml}$ blood) while the animal was anesthetized with ether. The animals were euthanized by cervical dislocation. The brain and testis were dissected and excised then one portion of each brain and testis was preserved in formalin buffer for the histopathological examination and the 
other portion was stored at $-80^{\circ} \mathrm{C}$ for molecular genetics study.

\section{Hormonal analyses}

The quantitative measurement of Luteinizing hormone (LH), Follicle stimulating hormone (FSH), serum Testosterone, Estradiol (E2) and Prolactin (PRL) were performed by Enzyme-Linked Immunosorbent Assay (ELISA) using Kamiya Biomedical Company rat LH ELISA kit and the data expressed as (mIU/ml), Biomatik rat FSH ELISA kit and the data expressed as (mIU/ml), Calbiotech mouse/rat estradiol ELISA and the data expressed as $(\mathrm{pg} / \mathrm{ml})$ and Abnova mouse/rat testosterone and PRL ELISA kit and the data expressed as $(\mathrm{ng} / \mathrm{ml})$ according manufacture structure.

5. Molecular genetics study (Quantitative real timepolymerase chain reaction (QRT-PCR)

The total RNA was isolated from the brain and testis tissues homogenate by RNA isolation kit (RN easy, Qiagen Ltd, Crawley, West Sussex, UK).

According to the manufacture instructions, the total RNA was quantified by the measured absorbance at 260/280 nm ratio (between 1.8 and 2.1) in a spectrophotometer. The purified RNA was converted into complementary DNA (cDNA) by reverse transcriptase (QuantiTect Reverse Transcription Kit, Qiagen, cat. No. 205310, Germany). The extracted RNA was used for expression of LH-B, FSH-B and cytochrome 19 (CYP-19) genes.

QRT-PCR reaction was carried out in $25-\mu \mathrm{L}$ reaction mixture containing $12.5 \mu \mathrm{L}$ of SYBR Green Real-time PCR Master Mix (Roche Diagnostics), $1 \mathrm{ml}$ of the forward primer, $1 \mu \mathrm{L}$ reverse primer, $2 \mu \mathrm{L}$ of $\mathrm{cDNA}$ and $8.5 \mu \mathrm{L}$ of distilled water. All samples were run in duplicates and PCR amplification consisted of 40 cycles of denaturation at $95{ }^{\circ} \mathrm{C}$ for $10 \mathrm{sec}$, annealing at $55^{\circ} \mathrm{C}$ for $10 \mathrm{sec}$ and extension at $72{ }^{\circ} \mathrm{C}$ for $20 \mathrm{sec}$. The primers were designed according to El-Habashi et al. (2013).

The hormonal related genes specific primers for FSH-B, LH-B and Cyp19 genes were purchased from (Bio-diagnostics-Egypt). The primers sequences that normalized on the bases of $ß$-actin are presented in Table 1.The cDNA amount in the reactions was normalized with internal control. The gene expressions were calculated as fold change from the formula: ${ }^{2-} \Delta \Delta \mathrm{CT}$ (Pfaffl, 2001).

\section{Histopathological Examination of brain and testis}

All tissue samples were fixed with $10 \%$ formalin. Consecutive $5-\mu \mathrm{m}$ thick sections from formalin-fixed, paraffin-embedded tissue blocks were prepared and stained with hematoxylin and eosin (H\&E) for histopathological examination (Frank et al., 2005).

\section{Statistical analysis}

Results were expressed as mean \pm standard deviation (SD). Multigroup comparisons of the means were carried out by one way analysis of variance (ANOVA) test. Least significant difference (LSD) test was used to compare the difference between the experimental groups, the untreated control group and vehicle groups .The statistical significance difference for all tests was set at $\mathrm{P}<0.05$ using SPSS software (v.19; SPSS).

\section{Results}

\section{Body weight}

The body weights mean values revealed nonsignificant differences between the vehicle groups (saline and citric acid) when compared to the untreated control group $(\mathrm{P}>0.05)$. The body weights of the brown heroin, tramadol and the concurrent brown heroin and tramadol groups showed significant reduction than those of the untreated control and vehicle groups $(\mathrm{P}<0.001)$ Table 2 .

\section{Hormonal assay}

The mean values of reproductive hormones of male rats serum LH $(\mathrm{mIU} / \mathrm{ml})$, FSH $(\mathrm{mIU} / \mathrm{ml})$, Testosterone $(\mathrm{ng} / \mathrm{ml}), \quad \mathrm{E} 2 \quad(\mathrm{pg} / \mathrm{ml})$ and PRL $(\mathrm{ng} / \mathrm{ml})$ revealed a non-significant differences between the vehicle groups (saline and citrus) when compared to the untreated control group $(\mathrm{P}>0.05)$.

Administration of brown heroin in group (IV), tramadol in group (V) and concurrent brown heroin and tramadol in group (VI) caused significant reduction in serum LH, FSH and Testosterone with significant increase in serum E2 and PRL when compared to the untreated control and vehicle groups levels $(\mathrm{P}<0.001)$ Table 3.

\section{Gene Expression Analysis}

The expression level mean values of hormonal related genes revealed non-significant differences between the vehicle groups (saline and citrus) when compared to the untreated control group $(\mathrm{P}>0.05)$.

Furthermore, in brown heroin group (IV), tramadol group (V) and concurrent brown heroin and tramadol group (VI); the expression level of FSH-B and LH-B genes in brain tissue of adult male rats showed significant reduction $(\mathrm{P}<0.001)$ While the expression level of Cyp-19 gene in the testicular tissue of rats showed significant increment $(\mathrm{P}<0.001)$ when compared to the untreated control and vehicle groups Table 4.

\section{HISTOPATHOLOGICAL RESULTS}

tissues

\section{Histopathological Evaluation of brain}

Examination of Hematoxylin and Eosin (H\&E) stained brain tissue sections of control and vehicle groups showed normal histological structure of meningeal coverings, cerebral cortex grey matter, white matter, hippocampus and cerebellum. So we used untreated control group (I) as a control group to be compared with other treated groups.

The evaluation of cerebral cortex grey matter sections in all studied groups. The sections of control groups showed grey matter which consisted of cell bodies showing an outer molecular layer covered by a delicate layer of pia matter, the external pyramidal layer. The external pyramidal layer showed cortical neurons with rounded pale nuclei surrounded by basophilic cytoplasm, different shapes of glial cells and few astrocytes with regular nuclei surrounded by pale cytoplasm, blood vessels with narrow perivascular spaces were also observed Figure 1a.

Examination of $\mathrm{H} \& \mathrm{E}$ stained brain tissue sections of brown heroin, tramadol and concurrent brown heroin and tramadol administrated groups showed disorganized histological structure of most sections of brain tissues. The grey matter of brown heroin group (IV) 
showed slight affection with separated pia matter, astrocytes showed irregular nuclei surrounded by pale cytoplasm and blood vessels showed wide perivascular spaces Figure 1b While the grey matter of tramadol (V) group showed mild separated pia matter, the outer molecular layer showed vacuolations and blood vessels with wide perivascular space. The external pyramidal layer showed some cortical neurons with darkly stained nuclei. Many astrocytes with irregular nuclei were also noticed Figure 1c.

Furthermore, the grey matter sections of concurrent brown heroin and tramadol group(VI), showed extensive changes when compared to control and even brown heroin and tramadol groups; in the form of wide outer molecular layer with marked vacuolations. There was extensive separation of pia matter and large congested blood vessels with wide perivascular spaces Figure 1d, the external pyramidal layer showed cortical neurons with darkly stained nuclei and surrounded by white spaces. Numerous astrocytes with irregular nuclei were noticed and blood vessels were surrounded by wide perivascular spaces Figure 1e.

The evaluation of cerebral cortex white matter sections in all studied groups. The white matter sections of control groups showed longitudinal and transverse sections of nerve fibers and oligodendroglia cells arranged in rows between these fibers. The nerve fibers appeared with central axons and surrounded by unstained myelin sheaths Figure 2a.

The white matter of brown heroin group (IV) showed reduced number of oligodendrocytes. Some nerve fibers showed unstained myelin sheaths and others lost their central axons with irregular surrounding of myelin sheath Figure 2b. The white matter of tramadol group (V) showed reduced irregularly distributed oligodendrocytes and inflammatory cells of variable sizes were also noticed between nerve fibers Figure 2c.

Furthermore the white matter sections of concurrent brown heroin and tramadol group (VI) showed massive affection include few and irregular distributed oligodendrocytes between the nerve fibers. The nerve fibers lost their central axons with irregular surrounding of myelin sheath. Variable sized inflammatory cells and hemorrhage between nerve fibers were found Figures 2d and 2 e.

The evaluation of the hippocampus sections in all studied groups. The hippocampus sections of control groups showed three layers: molecular, pyramidal and polymorphic. The thick pyramidal layer had closely packed rounded nerve cells with open faced nuclei and prominent nucleoli. Small blood vessels with narrow perivascular spaces and few astrocytes appeared in the surrounding acidophilic neuropil Figure 3a.

The hippocampus sections of brown heroin group (IV) showed decreased number of rounded nerve cells that showed dark stained pyknotic nuclei with dark basophilic cytoplasm in pyramidal layer. Astrocytes were increased in number and showed sharply demarcated nuclei and wide irregular pale area of cytoplasm. The blood vessels showed wide peri-vascular spaces in surrounding neutropil Figure $3 \mathbf{b}$. While, the hippocampus of tramadol group (V) showing similar changes with fewer number of rounded nerve cells in pyramidal layer Figure 3c.

Furthermore, the hippocampus of the concurrent brown heroin and tramadol (VI) showed reduction in the thickness of the pyramidal layer and absence of the nerve cells that were replaced with dark stained pyknotic nuclei. Astrocytes were numerous in number with sharply demarcated nuclei and wide irregular pale areas of cytoplasm. Blood vessels with wide peri-vascular spaces could be seen in surrounding vacuolated neuropil Figure 3d.

The evaluation of the cerebelleum sections in all studied groups. The cerebellum of control groups showed three layers; the molecular layer with superficial stellate cells and basal basket cells, the Purkinji cell layer which showed a single layer of large pyriform cells with vesicular nuclei and peri-neural Bergman cells with rounded nuclei and pale cytoplasm. And the granular layer composed of tightly packed small rounded cell nuclei and clear spaces (cerebellar islands) Figure 4a.

The cerebellar cortex of brown heroin group(IV) showed the basket cells and stellate cells of the molecular layer with darkly stained nuclei. The purkinji layer cells showed dark nuclei and increased number of peri-neural Bergman cells Figure $\mathbf{4 b}$. While, the cerebellar cortex of tramadol group(V) showed the basket cells and stellate cells of the molecular layer had darkly stained nuclei, The purkinji layer had many empty spaces representing lost purkinji neurons; the other neurons have dark nuclei and excess number of peri-neural Bergman cells Figure 4c.

Furthermore, the cerebellar cortex of the concurrent brown heroin and tramadol (VI) showed the molecular layer cells had darkly stained nuclei and wide perineural spaces. The purkinji layer had many empty spaces representing lost purkinji neurons and the other neurons had dark nuclei Figure 4d.

\section{Histopathological Evaluation of testicular} tissue.

Examination of $\mathrm{H} \& \mathrm{E}$ stained testicular tissue sections of control groups showed normal histological structure in the form of closely contact seminiferous tubules lined with stratified germinal epithelium (germ cells), the supporting sertoli pyramidal cells and clusters of interstitial cells of Leydig were observed in the connective tissue stroma in between the tubules. The spermatogenic cells were seen in regularly arranged row were arranged from the basement membrane to the lumina of the tubules starting from spermatogonia, primary spermatocytes and spermatids till mature spermatozoa in the lumina Figure 5a.

Examination of testicular tissues of brown heroin group (IV) showed wide separated seminiferous tubules and some tubules were resting on an irregular basement membrane. Wide interstitial spaces showing clusters of interstitial cells and exudates were noticed Figure 5b. The testicular tissues of tramadol group (V) showed wide interstitial spaces with vacuolated scanty interstitial cells and filled with exudates. Irregular distribution of germinal epithelium was also noticed Figure 5c. 
Furthermore, the testicular tissues of the concurrent brown heroin and tramadol group(VI) showed irregular seminiferous tubules with disorganized germinal epithelium and irregular basement membrane. Congested blood vessels were found with thickening of the vascular wall. The interstitial tissues showed wide spaces, inflammatory exudates, congested blood vessels with thickened vascular walls and vacuolated interstitial cells. Interstitial cells of Leyding showed pyknotic nuclei and were decreased markedly in number Figures 5d and5e.

Table (1): Hormone related specific genes primers used for quantitative RT-PCR

\begin{tabular}{|l|l|l|l|l|}
\hline Gene & Primer & MW & L & Gene bank accession no \\
\hline LH- B & Forward:5'-TCT CAC CACCAC CGT CTG TA-3' & 5972.92 & 20 & NM-001033975 \\
& Reversed:5'-TGC AGT CGC TGT AGT CC ATC-3' & 6084.00 & 20 & \\
\hline \multirow{2}{*}{ FSH-B } & Forward:5'-GGG CCA GGA ACT GTGAAA TA-3' & 6215.12 & 20 & NM-001007597 \\
& Reversed:5'-TCT CAG AAC TGC CGA GGT TT-3' & 6108.03 & 20 & \\
\hline CYP-19 & Forward: 5'-ATA CCA GGT CCT GGC TAC TG-3' & 6093.01 & 20 & NM-001348171.1 \\
& Reversed:5'-TTG TTG TTA AAT ATG ATG CC -3 & 6137.09 & 20 & \\
\hline \multirow{2}{*}{ 3-actin } & Forward: 5'-TTG CCG ACA GGA TGC AGA A-3' & 5861.88 & 19 & NM-031144 \\
& Reversed:5'-GCC GAT CCA CAC GGAGTA CT-3' & 6087.00 & 20 & \\
\hline
\end{tabular}

MW Molecular weight, L: Length of PCR product (base pairs), CYP-19 cytochrome 19

Table (2): Body weight of the studied groups after the treatment period

\begin{tabular}{|l|l|l|l|l|l|l|l|l|}
\hline \multicolumn{1}{|c|}{ Groups } & $\begin{array}{l}\text { Untreated } \\
\text { control (I) }\end{array}$ & $\begin{array}{l}\text { Saline } \\
\text { (II) }\end{array}$ & $\begin{array}{l}\text { Citric } \\
\text { acid } \\
\text { (III) }\end{array}$ & $\begin{array}{l}\text { Brown } \\
\text { heroin(IV) }\end{array}$ & $\begin{array}{l}\text { Tramadol } \\
\text { (V) }\end{array}$ & $\begin{array}{l}\text { Brown } \\
\text { heroin\& } \\
\text { Tramadol } \\
\text { (VI) }\end{array}$ & $\begin{array}{l}\text { F } \\
\text { test }\end{array}$ & $\begin{array}{l}\text { P } \\
\text { value }\end{array}$ \\
\hline $\begin{array}{l}\text { Body weight } \\
\text { (g) }\end{array}$ & $190.5 \pm 7.97$ & $189.1 \pm 6.1$ & $189.5 \pm 9.3$ & $95.3 \pm 4.8^{\mathbf{a}}$ & $94.2 \pm 6.1^{\mathbf{a}}$ & $93 \pm 5.8^{\mathbf{a}}$ & 874.1 & 0.000 \\
\hline
\end{tabular}

Results values are expressed as mean \pm standard deviation $(S D)$ (number $=10$ rats/group)., $P$ value of $>0.05=$ NonSignificant, ${ }^{a}$ Significant as compared with the untreated control and vehicle groups $(P<0.0001)$.

Table (3): Reproductive hormonal assays of the studied groups

\begin{tabular}{|l|l|l|l|l|l|l|l|l|}
\hline \multicolumn{1}{|c|}{ Groups } & $\begin{array}{l}\text { Untreated } \\
\text { control } \\
\text { (I) }\end{array}$ & Saline & Citric acid & $\begin{array}{l}\text { Brown } \\
\text { heroin (IV) }\end{array}$ & $\begin{array}{l}\text { Tramadol } \\
\text { (V) }\end{array}$ & $\begin{array}{l}\text { Brown } \\
\text { heroin\& } \\
\text { Tramadol } \\
\text { (IV) }\end{array}$ & $\begin{array}{l}\text { F test } \\
\text { value }\end{array}$ & $\begin{array}{l}\text { P } \\
\text { value }\end{array}$ \\
\hline LH(mIU/ml) & $0.95 \pm 0.24$ & $0.94 \pm 0.24$ & $0.91 \pm 0.21$ & $0.11 \pm 0.03^{\mathbf{a}}$ & $0.09 \pm 0.01^{\mathbf{a}}$ & $0.06 \pm 0.02^{\mathbf{a}}$ & 70.14 & 0.000 \\
\hline FSH(mIU/ml) & $0.78 \pm 0.14$ & $0.78 \pm 0.19$ & $0.75 \pm 0.27$ & $0.29 \pm 0.2^{\mathbf{a}}$ & $0.28 \pm 0.1^{\mathbf{a}}$ & $0.24 \pm 0.1^{\mathbf{a}}$ & 30.8 & 0.000 \\
\hline $\begin{array}{l}\text { Testosterone } \\
\text { (ng/ml) }\end{array}$ & $5.5 \pm 0.30$ & $5.5 \pm 0.6$ & $5.3 \pm 0.4$ & $1.9 \pm 0.4^{\mathbf{a}}$ & $1.7 \pm 0.3^{\mathbf{a}}$ & $1.5 \pm 0.6^{\mathbf{a}}$ & 203.05 & 0.000 \\
\hline E2 (pg/ml) & $44.74 \pm 1.82$ & $43.52 \pm 1.61$ & $42.48 \pm 1.72$ & $50.5 \pm 1.5^{\mathbf{a}}$ & $53.6 \pm 1.6^{\mathbf{a}}$ & $59.4 \pm 6.75^{\mathbf{a}}$ & 45.2 & 0.000 \\
\hline PRL (ng/ml) & $7.37 \pm 0.5$ & $6.40 \pm 0.4$ & $6.30 \pm 0.4$ & $11.33 \pm 0.7^{\mathbf{a}}$ & $12.2 \pm 0.6^{\mathbf{a}}$ & $14.23 \pm 0.5^{\mathbf{a}}$ & 411.6 & 0.000 \\
\hline
\end{tabular}

LH luteinizing hormone, FSH follicle-stimulating hormone, E2 Estradiol, PRL Prolactin, Results values are expressed as mean \pm standard deviation $(S D)$ (number $=10$ rats/group), $P$ value of $>0.05=$ Non-Significant, ${ }^{a}$ Significant as compared with the untreated control and vehicle groups $(P<0.0001)$.

Table (4): the reproductive related genes assays of the studied groups

\begin{tabular}{|l|l|l|l|l|l|l|l|l|}
\hline Groups & $\begin{array}{l}\text { Untreated } \\
\text { control (I) }\end{array}$ & $\begin{array}{l}\text { Saline } \\
\text { (II) }\end{array}$ & $\begin{array}{l}\text { Citric } \\
\text { acid } \\
\text { (III) }\end{array}$ & $\begin{array}{l}\text { Brown } \\
\text { heroin (IV) }\end{array}$ & $\begin{array}{l}\text { Tramadol } \\
\text { (V) }\end{array}$ & $\begin{array}{l}\text { Brown } \\
\text { heroin\& } \\
\text { Tramadol } \\
\text { (IV) }\end{array}$ & $\begin{array}{l}\text { F } \\
\text { test }\end{array}$ & $\begin{array}{l}\text { P } \\
\text { value }\end{array}$ \\
\hline LH-B gene & $1.1 \pm 0.1$ & $1.09 \pm 0.1$ & $1.1 \pm 0.1$ & $0.08 \pm 0.05^{\mathbf{a}}$ & $0.07 \pm 0.03^{\mathbf{a}}$ & $0.07 \pm 0.01^{\mathrm{a}}$ & 460.5 & 0.000 \\
\hline $\begin{array}{l}\text { FSH-B } \\
\text { gene }\end{array}$ & $1.08 \pm 0.1$ & $1.1 \pm 0.1$ & $1.08 \pm 0.1$ & $0.05 \pm 0.07^{\mathbf{a}}$ & $0.06 \pm 0.01^{\mathbf{a}}$ & $0.04 \pm 0.01^{\mathrm{a}}$ & 497.8 & 0.000 \\
\hline Cyp19gene & $1.04 \pm 0.03$ & $1.03 \pm 0.03$ & $1.05 \pm 0.06$ & $14.07 \pm 2.03^{\mathrm{a}}$ & $13.08 \pm 1.03^{\mathrm{a}}$ & $15.08 \pm 3.03^{\mathrm{a}}$ & 181.3 & 0.000 \\
\hline
\end{tabular}

LH-B luteinizing hormone beta subunit gene, FSH-B follicle-stimulating hormone beta subunit gene, CYP-19 cytochrome 19, Results values are expressed as mean \pm standard deviation (SD) (number $=10$ rats/group), $P$ value of $>0.05=$ Non-Significant, ${ }^{a}$ Significant as compared with the untreated control and vehicle groups $(P<0.0001)$. 

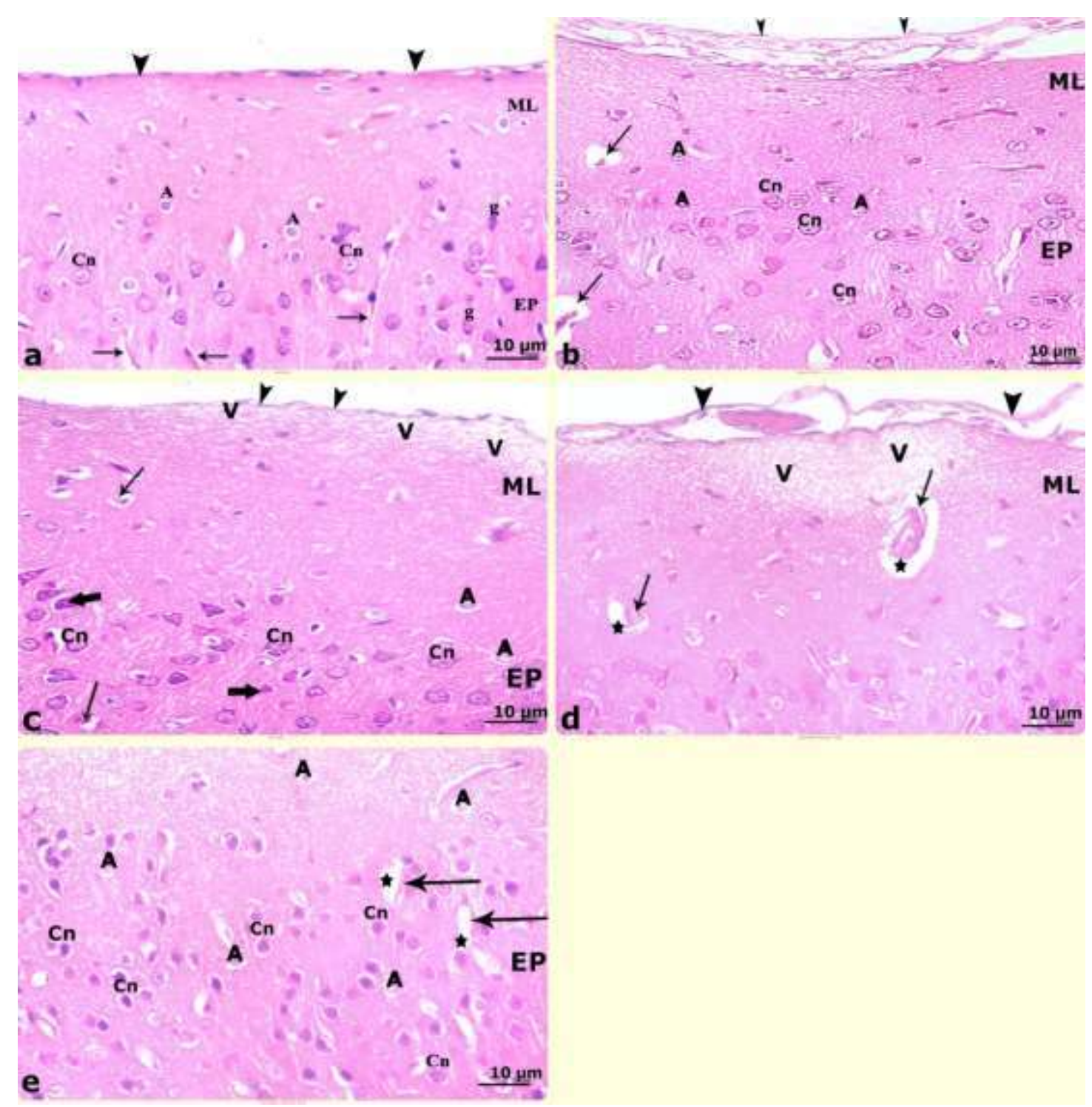

Figure (1). Photomicrographs of brain tissues (cerebral cortex grey matter). (a) control group are showing the grey matter covered by delicate layer of pia matter (arrow heads). The outer molecular layer (ML) and External pyramidal (EP) contains cortical neurons (Cn), glial cells (g), Astrocytes (A) with regular nuclei and blood vessels with narrow perivascular spaces (arrows). (b) brown heroin group show separated pia matter (arrow heads), Astrocytes (A) with irregular nuclei and blood vessels with wide perivascular spaces (arrows). (c) tramadol group show mild separated pia matter (arrow heads), vacuolations (V) and wide perivascular spaces (arrows) in (ML), while, the (EP) contains some (Cn) with darkly stained nuclei (thick arrows) and many astrocytes (A) with irregular nuclei. ( $d$ and e) concurrent brown heroin and tramadol group show in $d$ section extensive separation in pia matter (arrow heads), marked vacuolations (V), large congested blood vessels (arrows) with wide perivascular spaces (asterisk). In e section (Cn) with darkly stained nuclei surrounded by white spaces and enormous astrocytes (A) with irregular nuclei. H\&E X400 . 

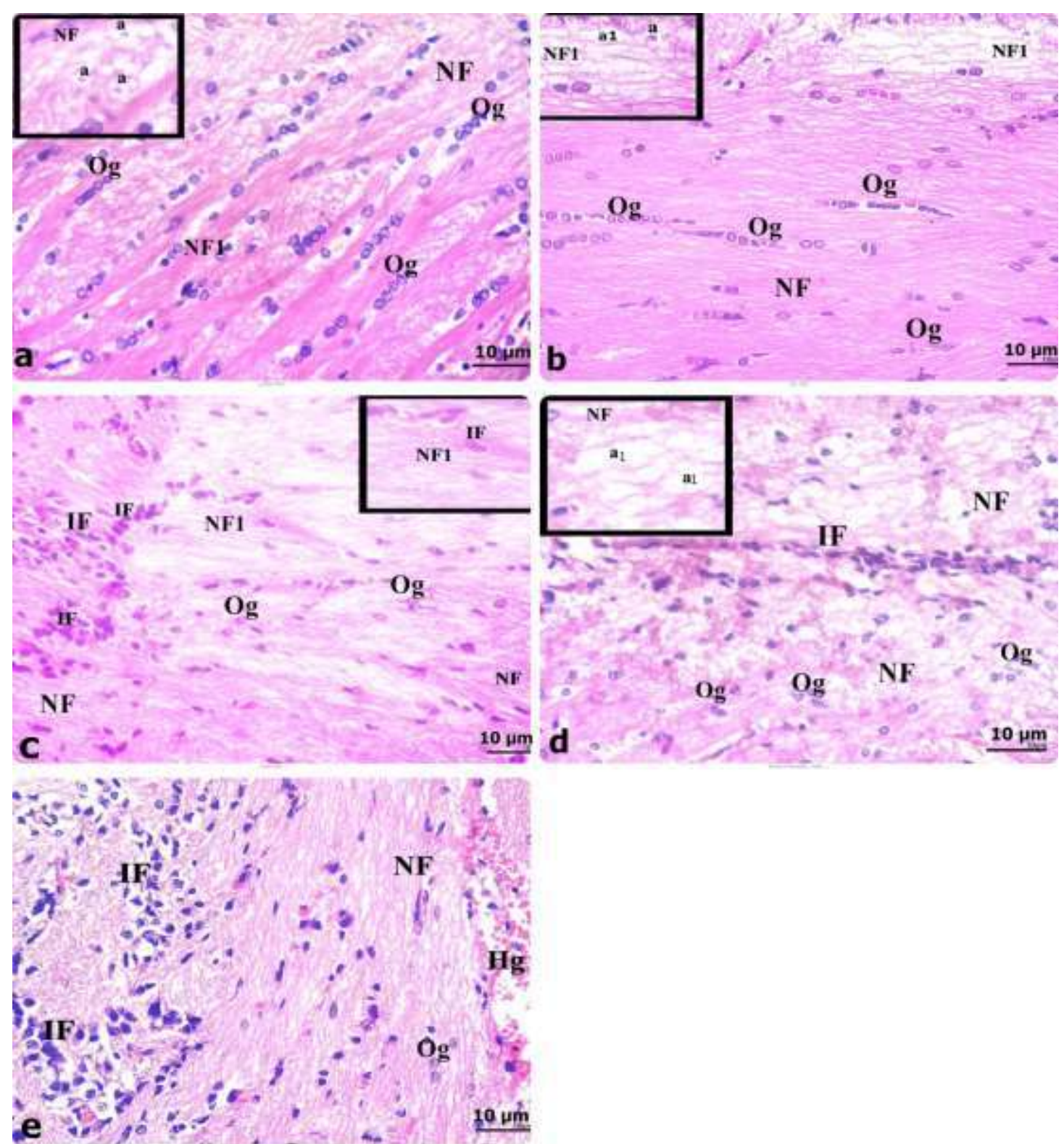

Figure (2). Photomicrographs of brain tissues (the cerebral cortex white matter). (a) control group are showing oligodendroglia cells $(\mathrm{Og})$ arranged in rows between the transverse nerve fibers (NF) and longitudinal nerve fibers (NF1). In the set nerve fibers (NF) with central axons surrounded by unstained myelin sheaths(a). (b) brown heroin group show some longitudinal nerve fibers (NF1) with central axons surrounded by unstained myelin sheaths (a) and other nerve fibers lost their central axons with irregular surrounding myelin sheath (a1) as in the set. (c) tramadol group show few irregularly distributed oligodendrocytes (Og) and variable sized inflammatory cells (IF) between nerve fibers (NF) as in the set. (d and e) concurrent brown heroin and tramadol group show few (Og) that irregularly distributed (arrows) and variable sized inflammatory cells (IF) and hemorrhage (Hg) between nerve fibers (NF) that lost their central axons with irregular surrounding myelin sheath(a1) as in the set. H\&E X400. 


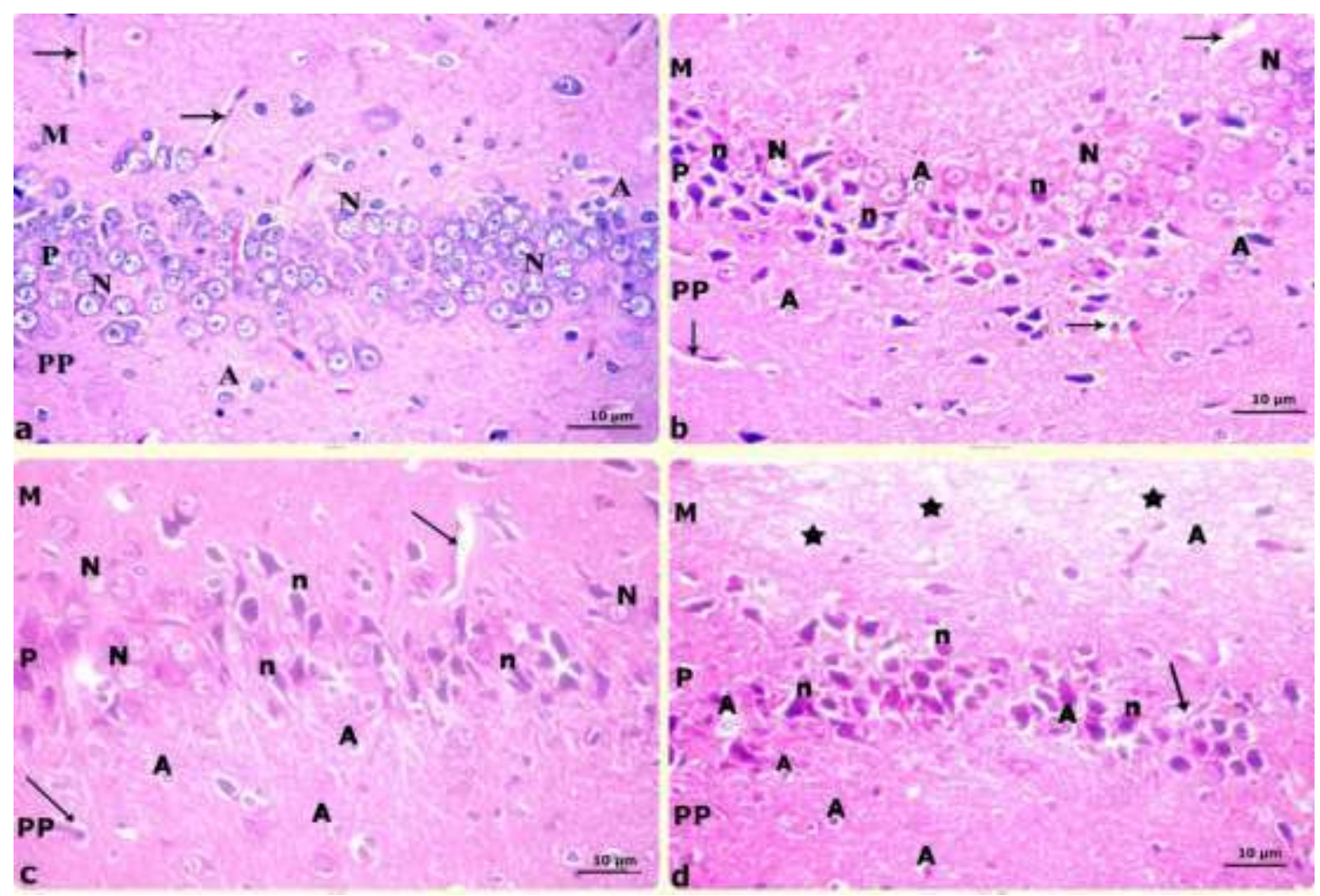

Figure (3). Photomicrographs of brain tissues (the hippocampus). (a) control group are showing molecular (M) layer, thick pyramidal (P) layer contains closely packed rounded nerve cells $(N)$, small blood vessels with narrow peri-vascular spaces (arrows) and few astrocytes (A) and the third polymorphic (PP) layer. (b) brown heroin group show decreased number of nerve cells. Some nerve cells with dark nuclei and dark basophilic cytoplasm(N) and others showing dark stained pyknotic nuclei (n). Astrocytes (A) are increased in number with sharply demarcated nuclei and wide irregular pale area of cytoplasm. The blood vessels with wide peri-vascular spaces (arrows). (c) tramadol group show the pyramidal layer (P) with nerve cells have dark nuclei and dark basophilic cytoplasm $(\mathrm{N})$ and increased number of cells with dark stained pyknotic nuclei(n) and many astrocytes (A). (d) concurrent brown heroin and tramadol group show the pyramidal layer (P) with thickness reduction, numerous dark stained pyknotic nuclei (n) with disappearance of nerve cells. Numerous astrocytes (A) with sharply demarcated nuclei and wide irregular pale area of cytoplasm. Blood vessels with wide perivascular spaces (arrows) can be seen in surrounding vacuolated neuropil (asterisk). H\&E X400. 


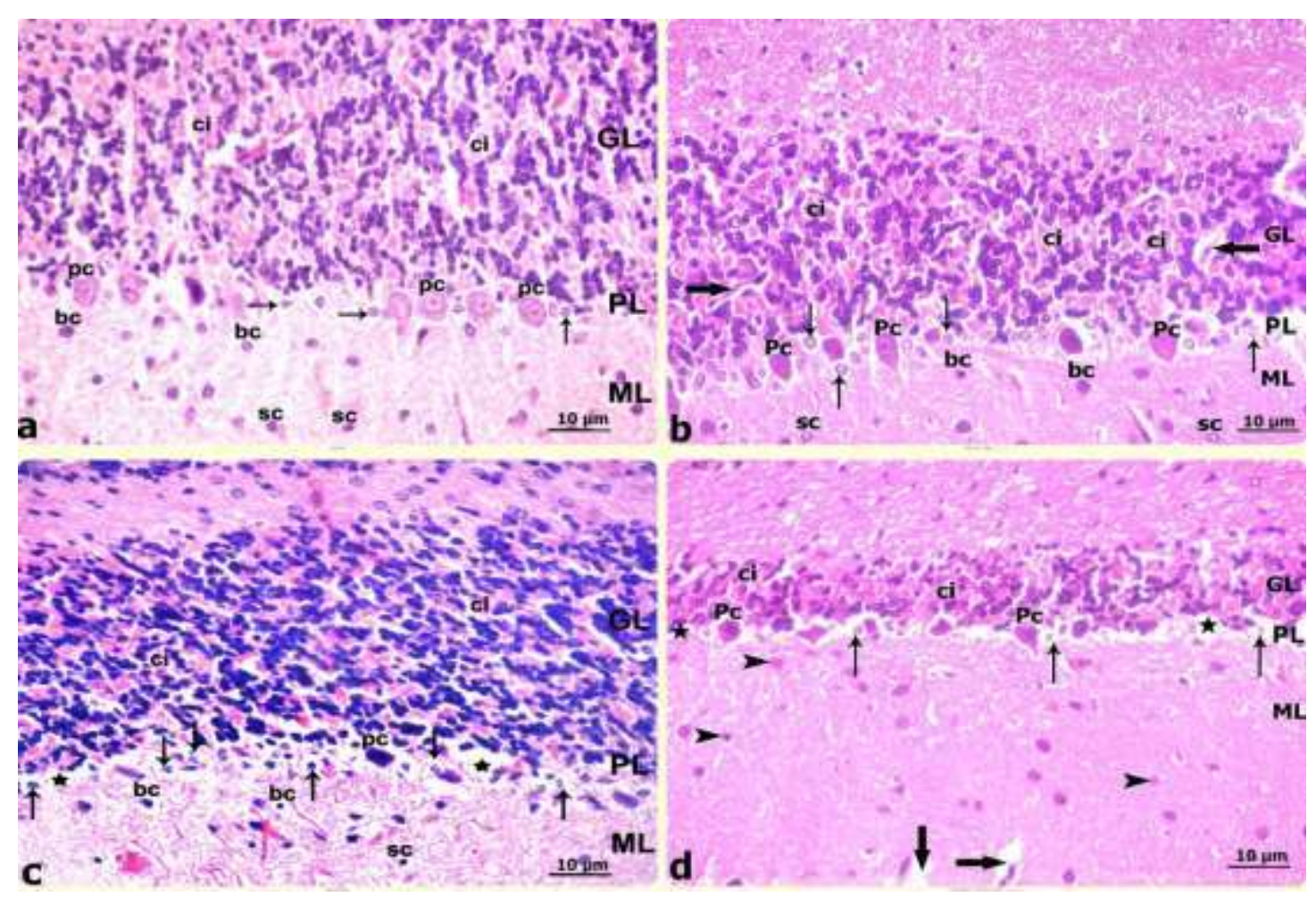

Figure (4). Photomicrographs of brain tissues (the cerebellum). (a) control group are showing the molecular layer (ML) with superficial stellate cells (sc) and basal basket cells (bc). The Purkinji cell layer (PL) with single layer of large pyriform cells (Pc) and peri-neural bergman cells (arrows) and the granular layer (GL) with cerebellar islands (ci). (b) brown heroin group show the basket cells (bc) and stellate cells (sc) of (ML) have darkly stained nuclei. The purkinji layer (PL) show (Pc) have dark nuclei and increase number of peri-neural bergman cells (arrows), while the granular layer (GL) appeared with clear cerebellar islands (ci) and invaded by blood vessels (thick arrows). (c) tramadol group show the basket cells (bc) and stellate cells (sc) of (ML) have darkly stained nuclei. The purkinji layer (PL) contain many empty spaces (asterisks) representing lost purkinji neurons; the other neurons (Pc) have dark nuclei and excess number of peri-neural bergman cells (arrows). (d) concurrent brown heroin and tramadol group show the molecular layer (ML) have darkly stained nuclei (arrow heads) and blood vessels with wide perineural space (thick arrows).The purkinji layer (PL) with empty spaces (asterisks) representing lost purkinji neurons; the other neurons (Pc) have dark nuclei and increase number of peri-neural bergman cells (arrows). H\&E X400. 


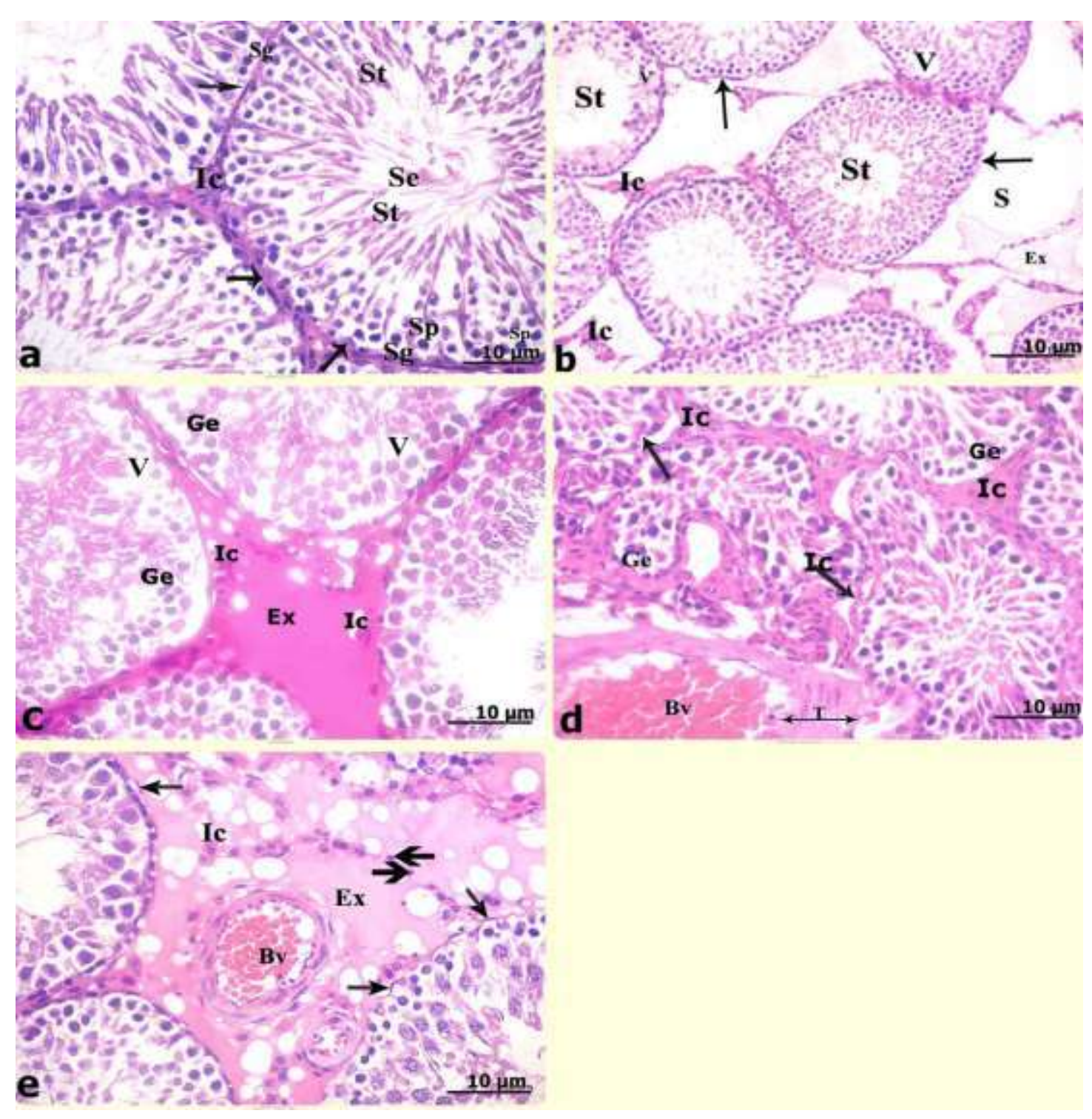

Figure (5). Photomicrographs of testicular tissues. (a) control group are showing closely contact seminiferous tubules (St) surrounded by regular basement membrane (arrows). Different types of spermatogenic cells; spermatogonia (Sg), primary spermatocytes (Sp) and aggregations of sperms (Se) are seen in their lumina. The interstitial spaces show clusters of interstitial cells (Ic) with oval nuclei and acidophilic cytoplasm.(b) brown heroin group showing semniferous tubules (St) with wide separation in between(S) and germinal epithelium showing vaculations (V). Some tubules with irregular basement membrane (arrows). Wide interstitial spaces showing clusters of interstitial cells(Ic) and exudate (Ex).(c)tramadol group showing wide interstitial space with vacuolated scanty interstitial cells(Ic) and exudates (Ex).The germinal epithelium(Ge)showing irregular distribution of vaculations (V).(d and e) concurrent brown heroin and tramadol group showing irregular seminiferous tubules with disorganized germinal epithelium (Ge) appeared on irregular basement membrane (arrows). Blood vessels are congested (Bv) with marked thickening of the wall (T). The interstitial spaces show exudate (Ex), vacuolated interstitial cells (Ic) and cells with pyknotic nuclei (thick arrows). H\&E X400.

\section{Discussion}

Addiction is considered a wide spread phenomenon around the world since a long time ago. Currently, multidrug abuse becomes a common habit between addicts especially in Egypt among young people and adolescents.

Brown heroin is considered the commonest and cheapest form of heroin in Egypt exceeding white heroin as its abuse pervaded among low and high socioeconomic abusers. Many addicts tend to abuse several drugs at the same time according to drug availability and cost of drug and so on.
Thus, in the present work, the effects of solely brown heroin, solely tramadol and the concurrent brown heroin and tramadol consumption on reproductive system were evaluated. Also, the manner and the route of drugs administration in adult male albino rats were adapted to conform the route and the manner of drugs administration among human addicts.

The results of the current study revealed a significant reduction in the body weights of adult male albino rats after administration of brown heroin, tramadol and the concurrent brown heroin and tramadol; 
respectively for 40 days when compared to the control values.

These results are consistent with those of previous studies; which reported weight reduction in heroin dependent mice for 40 days (Simin and Zahra, 2007). Another study showed that repeated tramadol administration lead to slower weight gain and reduction of food intake in intact rats (Liles and Flecknell, 1994 and Udegbunam et al., 2015).

The reduction of body weight induced by opioid and tramadol was attributed to the reduction of androgen synthesis that might be associated with reduction of its metabolism (Yilmaz et al., 1999) and to the major metabolite of tramadol (O-desmethyl tramadol) that affects the intestinal motility and inhibited peristalsis of small intestine more than the parent compound (Herbert et al., 2007). Moreover, presence of $\mu$-opioid receptors in the intestinal tract that leads to inhibition of the peristaltic action (Chen et al., 2012).

In our study, the continued weight loss in the groups dosed repeatedly with brown heroin, tramadol and concurrent brown heroin and tramadol suggested reduced food intake and direct opioid action.

Our study results showed significant reduction in serum LH, FSH and Testosterone with significant increase in E2 and PRL serum levels after brown heroin, tramadol and concurrent brown heroin and tramadol administration for 40 days when compared to the control values.

In agreement with our results, several researchers reported significant reduction of testosterone concentrations in heroin treated mice for forty days and heroin treated rats for seven successive days in both low and high dose; respectively (Simin and Zahra, 2007 and Othman, 2013). Other studies reported significant serum reduction of $\mathrm{LH}, \mathrm{FSH}$, Testosterone and elevated prolactin and E2 serum levels after tramadol administration in male rats for 4 weeks and 8 weeks, respectively (El-Gaafarawi, 2006 and Ahmed and Kurkar, 2014).

No studies have been conducted on the effects of concurrent brown heroin and tramadol administration on rat male reproductive hormones evaluation. However the results showed synergistic detrimental effects.

The alteration of serum reproductive hormones has several explanations. It was reported that the endogenous opioid peptides that modulate the opioid system play a considerable role in controlling central hypothalamic gonadotropin hormone (GnRH) and pituitary LH; (Burstein et al., 2013). Thus administration of exogenous opiates has been shown to decrease the levels of LH (Takzare et al., (2016), decrease the GnRH biosynthesis by blocking its release and reducing the neuro-peptide biosynthesis ( $\mathrm{Li}$ and Pelletier, 1993) and it intensifies the responsiveness of the hypothalamus to negative feedback by testosterone (Gabriel et al., 1985) counter to blockade of endogenous opioid peptide receptor .

Furthermore, the testicular Sertoli cells contain opioid-binding sites (Fabbri et al., 1989) associated with production of endogenous opioid peptides in testis (Udegbunam et al., 2015); which suggest the peripheral action of endogenous and exogenous opioid and the probability of testosterone hormone synthesis blocking. Moreover, the opioid action may be regulated by the gonadal sex steroid hormones which are the end product of the axis (Vuong et al., 2010).

On the other hand, the high concentration of exogenous opioid inhibited the testosterone synthesis either directly by increased prolactin levels (Pimpinelli et al., 2006) or by increased aromatization of testosterone to estradiol leading to increased serum E2 levels (Ceccarelli et al., 2006), where serum testosterone level that is considered the main marker affecting estradiol is converted to estradiol by the action of aromatase in certain peripheral tissues (Simpson, 2003).

The present study also evaluated the effects of brown heroin, tramadol and concurrent brown heroin and tramadol administration on rat male reproductive related genes expression that showed down regulation of FSH-B and LH-B in brain tissues with up regulation of CYP19 in testicular tissues. No studies have been conducted on the effects of neither brown heroin nor tramadol on rat male reproductive related genes expression.

The follicle stimulating hormone (FSH) and (LH) are functionally related hormones regulating the reproductive function centrally, In males; LH stimulates testosterone production in Leydig cells (Moyle and Campbell, 1996), While FSH promotes proliferation of sertoli cell that helps spermatogenesis (Plant and Marshall, 2001).

The pituitary glycoprotein hormone family consists of identical alpha subunit and a hormonespecific beta subunit, the beta-subunit is a mature protein that is encoded by the FSH-B and LH-B gene (4262 and 1111bp as a gene length) at chromosome 11p13 and 19q13.32;respectively (Nagirnaja et al., 2010).

Cytochrome 19 is a single gene located on chromosome 15 which is a member of the cytochrome P450 gene family, it is responsible for encoding aromatase enzyme which is an important enzyme which ensures the irreversible conversion of androgens into estrogens and is localized in endoplasmic reticulum of various tissues especially the gonads and is considered the fingerprint for detection of past profile of spermatogenesis (Carreau et al., 2008).

The down regulation of brain tissues genes expression can be attributed to that; the gonadotropin subunit mRNAs (LH-B and FSH-B) level usually affects the production of $\mathrm{LH}$ and FSH directly; each of gonadotropin subunit mRNAs is increased by $\mathrm{GnRH}$ (Kaiser et al., 2000). The chronic administration of opioid reduced the testosterone levels that lead to central reduction of LH release by reduction of hypothalamic $\mathrm{GnRH}$ beside the peripheral effects of opioid on the testis (Katz, 2005).

The up regulation of Cytochrome19 gene can be attributed to increased aromatization of testosterone to E2 because of the most circulating estradiol is derived from direct testicular secretion or from conversion of testicular androgens (De Ronde et al., 2005). 
The histopathological brain tissues results of brown heroin, tramadol and concurrent brown heroin and tramadol administration for 40 days revealed disorganized histological structure when compared to control group.

The histopathological brain tissues results of brown heroin group (IV) showed slightly affected grey matter sections with separated pia matter, the white matter showed nerve fibers that lost their central axons with irregular surrounding myelin sheath, the hippocampus showed decrease a number of nerve cells with dark stained pyknotic nuclei and dark basophilic cytoplasm. Astrocytes were increased in number in all sections and showed sharply demarcated nuclei and wide irregular pale area of cytoplasm and the blood vessels showed wide peri-vascular spaces. While, the cerebellar cortex sections showed the molecular layer cells with darkly stained nuclei. The purkinji layer had dark nuclei and increased number of peri-neural bergman cells.

No studies have been conducted on the brown heroin effects on the histopathological brain tissues sections. However, some studies reported that opioid had noxious effects on neuronal structure leading to neuronal damage by long term use (Liu et al., 2013). Atici et al. (2004) reported that chronic use with increasing doses for more than four weeks of morphine induced red neuron degeneration in different brain sections indicating hypoxic changes that might contribute to cerebral dysfunction.

The histopathological brain tissues results of tramadol group(V) showed grey matter sections with mild separated pia matter, vacuolations, , some cortical neurons with darkly stained nuclei. The white matter sections showed few irregular distributed oligodendrocytes and variable sized inflammatory cells. The hippocampus showed less number of rounded nerve cells. Many astrocytes were shown with irregular nuclei surrounded by pale cytoplasm and wide perivascular spaces. The cerebellar cortex sections showed the molecular layer cells had darkly stained nuclei. The purkinji layer had many empty spaces representing lost purkinji neurons; the other neurons had dark nuclei and excess number of peri-neural bergman cells.

These results are consistent with Mohamed et al. (2013), Abou El Fatoh et al. (2014) and Ghoneim et al. (2014) in their study on tramadol effects on brain of male rats, who reported loss of pyramidal cells shape, increased perivascular space with hemorrhage and cellular infiltrate, marked disorganization of the cortical layers and vacuolations besides shrunken irregular pyramidal cells with dark stained pyknotic nuclei and neural degeneration and congestion of submeningeal blood vessels respectively.

The histopathological brain tissues results of concurrent brown heroin and tramadol group (VI) showed grey matter with extensive separation of pie matter, marked vacuolations, irregular pyramidal cells with darkly stained degenerated nuclei, the white matter showed irregularly distributed oligodendrocytes and lost axons of nerve fibers, the hippocampus showed reduction in both of thickness of its pyramidal layer and the number of nerve cells that showed degeneration features, the cerebellar cortex showed darkly stained nuclei of molecular layer cells and degenerated purkinji neurons.

Moreover, numerous astrocytes were associated with sharply demarcated nuclei and wide irregular pale areas of cytoplasm, extensive inflammatory cellular infiltrate and the blood vessels in different sections of brain tissues showed congestion, spaces widening and hemorrhage.

No previous studies have been conducted on the effects of concurrent brown heroin and tramadol on histopathological brain tissues sections. However, the results showed extensive detrimental affection of brain tissues than that of brown heroin or tramadol alone.

The brain is the most affected organ in addiction either by direct action of the addicting agents or by disturbance in the physiological pathways especially by opioid effects that are mediated through opioid receptors. Several studies reported the importance of astrocytes which are a type of glial cells and play important physiological roles in brain functions as release of several neurotrophic factors that are responsible for maintenance of CNS homeostasis and react to various neurodegenerative insults (Eng et al., 1992), and contribute to the integrity of the blood brain barrier (Nishino et al., 1997).

The alteration of astrocyte number may be attributed to oxidative stress and free radical formation (Baydas et al., 2003) or the changes in gene expression and cellular changes (Sofroniew and Vinters, 2010).

The current histopathological results of testicular tissues of brown heroin, tramadol and concurrent brown heroin and tramadol administration for 40 days revealed distinct histological changes when compared to control group.

The histopathological results of testicular tissues of brown heroin group (IV) showed wide separation between seminiferous tubules and associated with irregular basement membrane. The interstitial spaces showed widening with clusters of interstitial cells and exudates.

No studies have discussed the effect of brown heroin on the testicular tissues. Heidari et al., (2012) reported arrested spermatogenesis, damaged sertoli cells and sloughed the germinal epithelium in seminiferous tubules with thickening and irregularities in the basement membrane after opiate exposure which is coincided with our results.

The histopathological results of testicular tissues of tramadol group (V) showed irregular distribution of germinal epithelium and wide interstitial space filled with exudates and vacuolated scanty interstitial cells.

The previous studies of tramadol exposure which coincided with our results, reported that tramadol caused affection of seminiferous tubules and reduction of spermatogenic cell populations (El-Gaafarawi, 2006; Mohamed et al., 2013; Abdellatief et al., 2015 and ElGhawet, 2015).

The histopathological results of testicular tissues of concurrent brown heroin and tramadol (VI) showed widely separated and vacuolated seminiferous 
tubules with irregular outline, disorganized germinal epithelium and reduction of spermatozoa. The intertubular tissues showed congested blood vessels, inflammatory cells and reduced number of interstitial cells of Leyding.

No studies have been conducted on the effects of concurrent brown heroin and tramadol on testicular tissues. However, the results showed extensive detrimental affection of testis that lead to affection of the function.

The researchers attributed the testicular histopathological results associated with opiates to the endocrine and paracrine disorders that affect the final size of sertoli cell population indirectly by affection of LH, GnRH, prolactin, estradiol, somatotropin and somatostatin hormones (Caju et al., 2011).

Another explanation is opiate induced reduction of serum testosterone level besides the structural and functional abnormalities of the secondary sex organs, and therefore opiates could affect testis volume and induce arrested spermatogenesis (Heidari et al., 2012).

\section{Conclusion}

In conclusion, regarding the present results, the concurrent brown heroin and tramadol dependency affect the hypothalamic-pituitary -gonadal axis (reproductive axis). The results suggest that the concurrent brown heroin and tramadol dependency could impair fertility in adult male albino rats by alteration of serum reproductive hormonal levels, down regulation of brain FSH-B and LH-B genes expression and up regulation of testicular Cyp-19 gene expression. Moreover, alteration of histological structure of both of brain and testicular tissues besides severe reduction in body weight occurred as a result of dependency.

\section{Acknowledgements}

Great thanks and gratefulness to Drugs control administration with in Security Directorate in Zagazig, Al-Sharqia for the great collaboration in this work.

\section{Funding}

This research did not receive any specific grant from funding agencies in the public, commercial, or not-forprofit sectors.

\section{Declaration of conflicting interests}

The authors declared no potential conflicts of interest with respect to the research, authorship, and/or publication of this article.

\section{References}

Abdellatief RB, Elgamal DA and Mohamed EE (2015): Effects of chronic tramadol administration on testicular tissue in rats: an experimental study. Andrologia, 47: 674-679.

Abou El Fatoh MF, Farag M, Sayed AE, et al., (2014): Some Biochemical, Neurochemical, Pharmacotoxicological and Histopathological Alterations Induced by Long-term Administration of Tramadol in Male Rats. Int. J. Pharm. Sci., 4 : 565-571.

Adams EH, Breiner S, Cicero T, et al., (2006): Comparison of the Abuse Liability of Tramadol, NSAIDs and Hydrocodone in Patients with Chronic Pain. J. Pain Manage, 3: 465-476.
Ahmed MA and Kurkar A (2014): Effects of opioid (tramadol) treatment on testicular functions in adult male rats: The role of nitric oxide and oxidative stress. Clin. Exp. Pharmacol. Physiol., 41:317-323.

Akbari E, Mirzaei E and Shahabi N (2013): Long term morphine-treated rats are more sensitive to antinociceptive effect of diclofenac than the morphinenaive rats. Iran J. Pharm. Res., 12: 175-184.

Antonilli L, Suriano C, Paolone G, et al., (2003): Repeated exposures to heroin and/or cadmium alter the rate of formation of morphine glucuronides in the rat. J. Pharmacol. Exp. Ther., 307: 651-660.

Atici S, Cinel L, Cinel I, et al., (2004): Opioid neurotoxicity: comparison of morphine and tramadol in an experimental rat model. Int. J. Neurosci., 114 :1001-1011.

Baydas G, Nedzvetskii VS, Tuzcu M, et al., (2003): Increase of glial fbrillary acidic protein and S100B in hippocampus and cortex of diabetic rats: effects of vitamin E. Eur. J. Pharmacol., 462:67-71.

Burstein SR, Williams TJ, Lane DA, et al., (2013): The influences of reproductive status and acute stress on the levels of phosphorylated delta opioid receptor immunoreactivity in rat hippocampus. Brain Res., 1518: 71-81.

Caju FM GC, Gian C, Queiroz D, et al., (2011): Opioid system manipulation during testicular development: results on sperm production and sertoli cells population. Acta Scientiarum Biological Sciences, 33 :219-225.

Carreau S, De Vienne C and Galeraud-Denis I (2008): Aromatase and estrogens in man reproduction: a review and latest advances. Advanc. Medic. Sci., 53: 139-144 .

Ceccarelli I, De Padova AM, Fiorenzani P, et al., (2006): Single opioid administration modifies gonadal steroids in both CNS and plasma of male rats. Neuroscience, 140: 929-937.

Chen W, Chung HH. and Cheng JT (2012): Opiateinduced constipation related to activation of small intestine opioid $\mu 2$-receptors, Worl. $\mathrm{J}$. Gastroenterol., 18:1391-1396.

Dambisya YM, Wong CL and Chan K (1991): Effects of sympathomimetic agents on opiate analgesia, tolerance and dependence in mice. Methods Find Clin. Pharmacol., 13: 239-248.

De Ronde W, Hofman A, Pols HA and de Jong FH (2005): A direct approach to the estimation of the origin of oestrogens and androgens in elderly men by comparison with hormone levels in postmenopausal women. Eur. J. Endocrinol., 152: 261-268.

El-Gaafarawi E (2006): Biochemical Toxicity Induced By Tramadol Administration In Male Rats. Egy. J. Hospi. Med., 23: 353 - 362. DOI:journaldatabase.info/articles/biochemical_t 
oxicity_induced_by.html.(acessed on 27 Jan 2017).

El-Ghawet H A (2015): Effects of tramadol on the reproductive function of wistar albino rats. Euro J Exper Bio 5: 56-64.

El-Habashi AA, Mousa MA, El-Eraky WI, et al., (2013): Possible mechanisms for the toxic effects of marijuana smoke on the reproductive axis of male albino rats. J. Appl. Pharmace. Sci., 3: S59-S67.

Eng LF, Yu AC and Lee YL (1992): Astrocytic response to injury. Prog. Brain Res., 94:353-365.

Fabbri A, Jannini EA, Gnessi L, et al., (1989): Neuroendocrine control of male reproductive function. The opioid system as a model of control at multiple sites. J. Steroid Biochem., 32 : 145-150.

Frank JMF, Bernd DG and Kuwaki K (2005): Histopathology of spleen allograft rejection in miniature swine. Inter. J. Exp. Pathol., 86 :5766.

Fronczak CM, Kim ED and Barqawi ALB (2012): The Insults of illicit drug use in male fertility. J Andrology, 33:515-526.

Gabriel SM, Simpkins JW, Kalra SP, et al., (1985): Chronic morphine treatment induces hypersensitivity to testosterone-negative feedback in castrated male rats. Neuroendocrinolog., 40: 39-44.

Gholami M, Saboory E, Mehraban S, et al., (2015): Time Dependent Antinociceptive Effects of Morphine and Tramadol in the Hot Plate Test: Using Different Methods of Drug Administration in Female Rats. Iran J. Pharm. Res., 14: 303-311.

Ghoneim FM, Khalaf HA, Elsamanoudy AZ, et al., (2014): Effect of chronic usage of tramadol on motor cerebral cortex and testicular tissues of adult male albino rats and the effect of its withdrawal: histological, immunohistochemical and biochemical study. Int. J. Clin. Exp. Pathol., $7: 7323-7341$.

Ghowsi M and Yousofvand N (2015): Impact of morphine dependency and detoxification by methadone on male's rat reproductive system. Iran J. Reprod. Med., 13: 275-282.

Heidari Z, Mahmoudzadeh-Sagheb $\mathrm{H}$ and Kohan FA (2012): Quantitative and Qualitative Study of Rat Testis Following Administration of Methadone and Buprenorphine. Inter. J. Hig. Ris. Behavi. Addic., 1:14-17.

Herbert MK, Weis R and Holzer P (2007): The enantiomers of tramadol and its major metabolite inhibit peristalsis in the guinea pig small intestine via differential mechanisms. BMC Pharmacol., 7: 5.

Jones JD, Mogali S and Comer SD (2012): Polydrug abuse: A review of opioid and benzodiazepine combination use. Drug Alcohol Depend., 125:818.

Kaiser UB, Halvorson LM and Chen MT (2000): Sp1 stroidogenic factor 1 (SF-1), and early growth response protein 1 (egr-1) binding sites form a tripartite gonadotropin releasing response element in the rat luteninizing hormone- beta gene promoter: an integral role for SF-1. Mol. Endocrinol., 14:1235-1245.

Katz N (2005): The impact of opioids on the endocrine system, Pain Manag., 19 :1-6.

King LA and McDermott S (2004): Drugs of abuse. in: A.C. Moffat, M.D. Osselton, B.Widdop, (Eds.), Clarke's analysis of drugs and poisons, third ed. Pharmaceutical Press, London, Vol. 1, pp. 3752.

Klous MG, Van den Brink W, Van Ree JM, et al., (2005): Development of pharmaceutical heroin preparations for medical co-prescription to opioid dependent patients. Drug Alcohol Depend., 80: 283-95.

Li S and Pelletier G (1993): Opioid regulation of gonadotropinreleasing hormone gene expression in the male rat brain as studied by in situ hybridization. Neuroreport., 4: 331-333.

Liles JH and Flecknell PA (1994): A comparison of the effects of buprenorphine, carprofen and flunixin following laparotomy in rats. J. Vet. Pharmaco. Therap., 17: 284-290.

Liu LW, Lu J, Wang XH, et al., (2013): Neuronal apoptosis in morphine addiction and its molecular mechanism. Int. J. Clin. Exp. Med., 6:540-545.

Malik SA , Khan C , Jabbar A , et al., (1992): Heroin addiction and sex hormones in males. J. Pak. Med. Assoc., 42(9) :210-212.

Matthiesen T, Wöhrmann T, Coogan TP, et al., (1998): The experimental toxicology of tramadol: an overview. Toxicol. Lett., 95: 63-71.

McCance EF, Price LH, Kosten TR, et al., (1995): Cocaethylene pharmacology, physiology and behavioral effects in humans. J. Pharmacol. Exp. Ther., 274:215-223.

Mohamed TM, Ghaffar HM and El Husseiny RM (2013): Effects of tramadol, clonazepam, and their combination on brain mitochondrial complexes. Toxicol. Ind. Health, 31 : 13251333.

Moyle W and Campbell R (1996): Gonadotropins, In: E. Adashi, J. Rock, Z. Rosenwaks, (Eds.), Reproductive Endocrinology, Surgery and Technology, Lippincott-Raven Publishers, Philadelphia.

Nagirnaja L, Rull K, Uusküla L , et al., (2010): Genomics and genetics of gonadotropin betasubunit genes: Unique FSHB and duplicated LHB/CGB loci. Mol. Cell Endocrinol., 329 : 416.

Nishino H, Kumazaki M, Fukuda A, et al., (1997): Acute 3-nitropropionic acid intoxication induces striatal astrocytic cell death and dysfunction of the blood-brain barrier: involvement of dopamine toxicity. Neurosci. Res., 27:343-355.

Othman GQ (2013): Evaluation of Oxidative Markers, Apoptosis and Reproductive Efficiency in 
Heroin Addicted Rats. IOSR J. Pharmacy, 3:17.

Paget GE and Barnes JM (1964): Evaluation of drug activities in: D.R. Laurence, A.L. Bacharach (Eds), Pharmacometrics, Academic Press, London, vol. 1, pp.135.

Pfaffl MW (2001): A new mathematical model for relative quantification in real-time RT-PCR. Nucleic Acids Res., 29: e45.

Pimpinelli F, Parenti M, Guzzi F, et al., (2006): Presence of delta opioid receptors on a subset of hypothalamic gonadotropin releasing hormone (GnRH) neurons. Brain Res., 1070 : 15-23.

Plant TM and Marshall GR (2001): The functional significance of FSH in spermatogenesis and the control of its secretion in male primates. Endocr. Rev., 22: 764-786.

Simin F and Zahra T (2007): Effect of heroin in Iran on male infertility of mice. Inter $\mathrm{J}$ pharmaco 3 : 406-410.

Simpson ER (2003): Sources of estrogen and their importance, J. Steroid Biochem. Mol. Biol., 86: 225-230.
Sofroniew MV and Vinters HV (2010): Astrocytes: biology and pathology. Acta. Neuropathol ., 119:(1) 7-35.

Takzare N, Samizadeh E, Shoar S, et al., (2016): Impacts of morphine addiction on spermatogenesis in rats. Int. J. Reprod. Bio. Med., 14:303-308.

Udegbunam RI, Okereke HN and Udegbunam SO (2015): Single versus repeated tramadol injection in laparotomized albino rats: comparison of effects on hematology, serum biochemical parameters, and body weight gain. J. Adv. Vet. Anim. Res., 2:316-320.

Vuong C, Van Uum SHM, O'Dell LE, et al., (2010): The Effects of opioids and opioid Analogs on Animal and Human Endocrine Systems. Endocr. Rev., 31: 98-132.

Yilmaz B, Konar V, Kutlu S, et al., (1999): Influence of chronic morphine exposure on LH, FSH and testosterone concentration and body and testicular weights in the developing male rat. Arch. Androl., 43:189-196.

\section{تأثير ادمان الميروين البني والترامادول على مسار الانجاب لذكور الجرذان البيضاء البالغة}

$$
\begin{aligned}
& \text { داليا إبراهيم أحمد مسلم و أروي أحمد الثيخ ا و سما صلاح عبد الفتاحَ نهي محمد عبد السلا؟ب } \\
& \text { ويعتبر إدمان المخدرات مشكلة كبيرة في جميع أنحاء العالم مسبيا بذلك آثار ا ضارة هائلة على المدمن نفسه والمجتمعات. }
\end{aligned}
$$

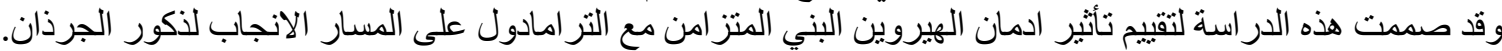

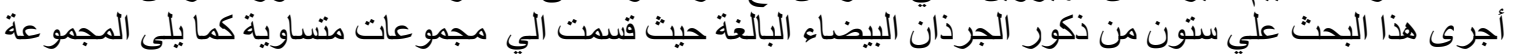

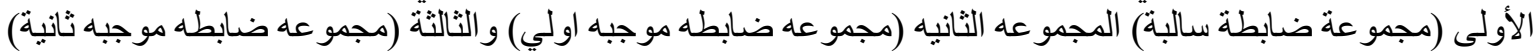

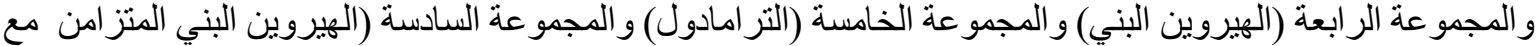

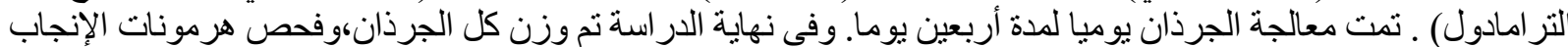

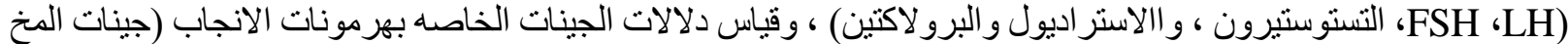

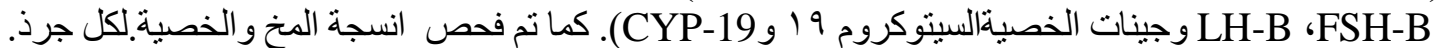

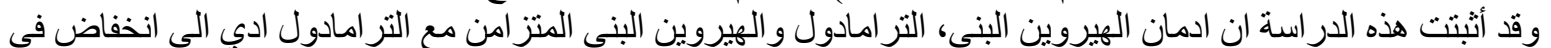

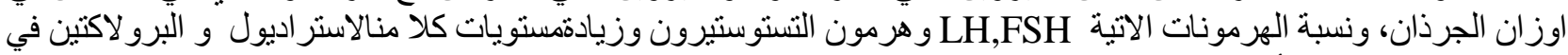

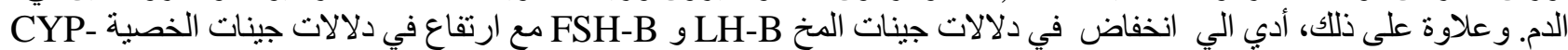

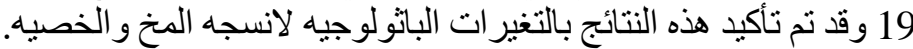

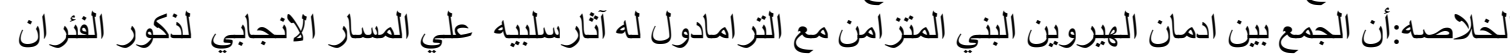
البيضاء البالغة

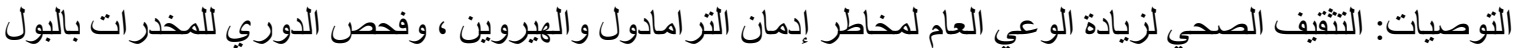

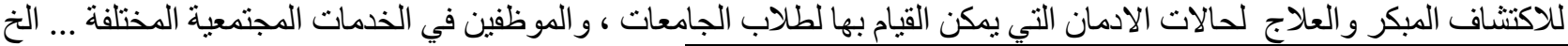

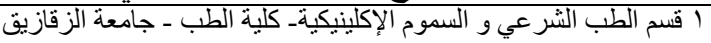

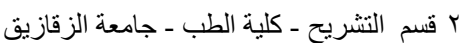

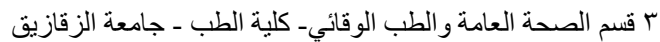

